\section{A study on inorganic fertilizers and organic materials to increase the productivity of rice crop (Oryza sativa L.) in equatorial agroecosystems}

\author{
Sution Sution, ${ }^{1}$ Agus Suryanto, ${ }^{2}$ \\ Mudji Santoso ${ }^{2}$ \\ ${ }^{1}$ Assessment Institute for Agricultural \\ Technology of West Kalimantan; \\ ${ }^{2}$ Department of Agronomy, Faculty of \\ Agriculture, Brawijaya University, \\ Malang, Indonesia
}

\begin{abstract}
The aim is to determine the optimum combination of inorganic fertilizer and organic materials for increasing the productivity of rice crop (Oryza sativa L.). The experiment was conducted in February-June 2015 in Kebadu, Sanggau, West Kalimantan, Indonesia. The study area was located at $00^{\circ} 0.08,785^{\prime} \mathrm{N}$ north latitude and $110^{\circ} 0.07,175^{\prime} \mathrm{E}$ east longitude with ultisol soil; the altitude is $32 \mathrm{~m}$ above sea level, rainfall level ranges between 185-267 mm month $^{-1}$, and the solar radiation is 375.49$452.58 \mathrm{cal} \mathrm{cm}^{-2} \mathrm{day}^{-1}$. This study used a factorial randomized block design. The first factor was the inorganic fertilization (without fertilizer, inorganic fertilizer 50\%, $100 \%$, and $150 \%$ ) and the second factor was the addition of organic materials $\left(\mathrm{EM}_{4} 21 \mathrm{ha}^{-1}\right.$, chicken manure $2 \mathrm{t} \mathrm{ha}^{-1}$, and manure $2 \mathrm{tha}^{-1}$ $+\mathrm{EM}_{4} 21 \mathrm{ha}^{-1}$ ). Results showed that the application of chicken manure and a combination of chicken manure $+\mathrm{EM}_{4}$ could reduce the need for inorganic fertilizer NPK by up to $50 \%$ with productivity that ranged from $4.18-4.20 \mathrm{t} \mathrm{ha}^{-1}$; this is relatively similar to $100 \%$ and $150 \%$ inorganic fertilizer NPK, and can increase the harvest by up to $68 \%$ compared to the no-NPK inorganic fertilizer.
\end{abstract}

\section{Introduction}

Currently, irrigated rice fields are used for paddy production. However, this is obstructed by the decline in soil fertility and the limited water for irrigation. Paddy production in dry land is one of the efforts to increase the productivity of rice crops. It is supported by the land potential in West Kalimantan that is fairly wide, with a width of 2.2 million ha. ${ }^{1}$ West Kalimantan has an equatorial agroecosystem that supports the development of rice crops. It is also supported by an average temperature of $27^{\circ} \mathrm{C}$, high air humidity because of its high air evaporation, bimolar rainfall patterns with two peaks of rainy season in April and December, an annual rainfall of $3095 \mathrm{~mm}$ year ${ }^{-1}$, sun that shines all year round, long exposure of 12 hours a day, and high intensity that reaches $452 \mathrm{cal} \mathrm{cm}^{-2}$ day $^{-1}$. However, the productivity of rice crops in West Kalimantan is still low: $1.88 \mathrm{t} \mathrm{ha}^{-1} .^{2}$

Farmers rarely use fertilization technology, which leads to low productivity of rice crops. NPK inorganic fertilizer is a macronutrient that is necessary for plant growth and increasing crop productivity. NPK fertilizer can be used to increase the number of tillers, leaf area, and protein synthesis, as well as the process of grain formation and grain filling in the vegetative phase of the plant. ${ }^{3}$ The element phosphorus plays a role in cuticle formation, root development, rod reinforcement, and the formation of fruits and seeds. ${ }^{4}$ Phosphorus application in the generative phase can stimulate flowering, fruit ripening, and the improvement of grain quality. ${ }^{5}$ Potassium can stimulate root growth, pest and disease resistance, and grain quality improvement, as well as reducing maturity caused by phosphor. The function of organic materials is to provide water and necessary nutrients for the plants, improve soil structure, and increase the development of microorganisms. A combination of inorganic fertilizer and organic materials is assumed to provide nutrients for the soil in a balanced way so that plants grow in a better way.

Manure from chicken is excrement from chickens that can be used as an organic fertilizer to improve the physical, chemical, and biological nature of the soil. It can neutralize the $\mathrm{pH}$, reducing heavy metals in the soil, improve soil structure and porosity, help with nutrient absorption from chemical fertilizers, improve water absorption, and maintain the temperature fluctuations of the soil. Effective Microorganism $\left(\mathrm{EM}_{4}\right)$ is useful for reducing the use of chemical fertilizers and pesticides, and improving the efficiency of organic materials for plants. ${ }^{6}$ In addition, $\mathrm{EM}_{4}$ is used to accelerate the decomposition of organic substances, increase the availability of nutrients for plants, suppress the activity of the pathogenic soil, reduce the need for chemical fertilizers and pesticides, and increase the activity of beneficial indigenous microorganisms. Fertilization based on changes in soil nutrient status is in line with technological developments. Therefore, the existing fertilizer needs to be reexamined and refined. ${ }^{7}$ The application of $\mathrm{EM}_{4}$ can be achieved by spraying it on the leaf surface. This is done to increase the activity of plant photosynthesis and suppress the pathogen growth
Correspondence: Sution, Postgraduate Programme, Faculty of Agriculture, Brawijaya University, Jl. Veteran, Malang 65145, Indonesia.

E-mail: tionsptk@yahoo.com

Key words: equator, EM4, manure, NPK, rice crop.

Acknowledgements: The authors would like to thank to the Agency for Agricultural Research (Badan Litbang Pertanian) and the Institute of Agricultural Technology of West Kalimantan (Balai Pengkajian Teknologi Pertanian Kalimantan Barat) for the research funding support.

Contributions: the authors contributed equally.

Conflict of interest: the authors declare no potential conflict of interest.

Received for publication: 6 April 2017.

Revision received: 11 August 2017.

Accepted for publication: 11 August 2017.

This work is licensed under a Creative Commons Attribution-NonCommercial 4.0 International License (CC BY-NC 4.0).

(C) Copyright S. Sution et al., 2018

Licensee PAGEPress srl, Italy

International Journal of Plant Biology 2018; 9:6529 doi:10.4081/pb.2018.6529

on plant surfaces. ${ }^{8}$ The purpose of this research is to identify the optimum combination of inorganic fertilizers and organic materials to increase the growth and productivity of rice crops.

\section{Materials and Methods}

This study was conducted in Kebadu, Sanggau, West Kalimantan. It is located at $00^{\circ} 0.08,785^{\prime} \mathrm{N}$ northern latitude and $110^{\circ} 0.07,175^{\prime} \mathrm{E}$ east longitude, at the altitude of $32 \mathrm{~m}$ above sea level; the average

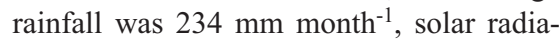
tion was $410 \mathrm{cal} \mathrm{cm}^{-2} \mathrm{day}^{-1}$, and the soil type was ultisol. An factorial randomized block design was used as the experimental design. It consisted of 2 factors and 3 repeats.

The first factor the inorganic fertilization, which consisted of:

(Po) treatment without fertilization

(P1) $50 \%$ inorganic fertilizer $\left(45 \mathrm{~kg} \mathrm{~N} \mathrm{ha}^{-1}\right.$, $18 \mathrm{~kg} \mathrm{P}_{2} \mathrm{O}_{5} \mathrm{ha}^{-1}, 30 \mathrm{~kg} \mathrm{~K}_{2} \mathrm{O} \mathrm{ha}{ }^{-1}$ )

(P2) $100 \%$ inorganic fertilizer $(90 \mathrm{~kg} \mathrm{~N}$ $\mathrm{ha}^{-1}, 36 \mathrm{~kg} \mathrm{P}_{2} \mathrm{O}_{5} \mathrm{ha}^{-1}, 60 \mathrm{~kg} \mathrm{~K}_{2} \mathrm{O} \mathrm{ha}^{-1}$ )

(P3) $150 \%$ inorganic fertilizer $(135 \mathrm{~kg} \mathrm{~N}$ $\mathrm{ha}^{-1}, 54 \mathrm{~kg} \mathrm{P}_{2} \mathrm{O}_{5}$ ha $^{-1}, 90 \mathrm{~kg} \mathrm{~K}_{2} \mathrm{O}$ ha $^{-1}$ )

The second factor was the application 
of organic materials, which consisted of:

(O1) $21 \mathrm{ha}^{-1}$ of $\mathrm{EM}_{4}$

(O2) $2 \mathrm{t} \mathrm{ha}^{-1}$ of chicken manure

(O3) $21 \mathrm{ha}^{-1}$ of EM4 and $2 \mathrm{tha}^{-1}$ of chicken manure

Observation parameters in this study were plant height, number of tillers of rice per clump, index of leaf area, total dry weight of plants per clump, growth rate of plants, number of panicles per clump, empty grain per clump (\%), weight of 1000 grains, and weight of dry milled grain per hectare. The data obtained from observations were analyzed using analysis of variance (F-test) with a 5\% confidence level $(\alpha)$ and continued with the LSD comparison test $(5 \%)$ to compare each of the treatments.

\section{Results and Discussion}

\section{Plant height}

The result of the study showed that the application of $150 \%$ inorganic fertilizer could increase crop height to be higher than that with no fertilizers. The application of $50 \%$ and $100 \%$ fertilizers was done at age 45-75 dap (rice plants vegetative phase). At 90-105 dap (generative phase), the application of $150 \%$ inorganic fertilizer resulted in the same plant height with $50 \%$ and $100 \%$ of inorganic fertilizer (Table 1). The combination of organic fertilizer and NPK provided high growth in plants, which was better than the application of only NPK fertilizer or only organic fertilizer. ${ }^{9}$ The availability of necessary nutrients in the soil affected the photosynthesis activity and caused an increase in the growth and harvest of products. ${ }^{10}$

\section{Number of tillers}

Observations 60 dap showed that $100 \%$ and $150 \%$ inorganic fertilizer treatment resulted in the same number of tillers. Treatment with $100 \%$ and $150 \%$ inorganic fertilizer resulted in an increased number of tillers than the 50\% inorganic fertilizer and no fertilizer at 75-105 dap (Table 2). Lack of nutrient affected the formation of new cells so that plant growth was obstructed. In addition, it caused dwarf plants and tiller formation was decreased. The provision of nitrogen played a role in the growth of stems and leaves, while phosphor was required for the formation of roots on young plants. ${ }^{11}$ Chicken manure and NPK could increase the plant height and number of tillers because it could provide macro- and micronutrients insufficient and balanced quantities. $^{3}$

\section{Index of leaf area}

The result showed that at the age of 90-
105 dap, $150 \%$ inorganic fertilizer had the same index of leaf area with $50 \%$ and $100 \%$ of inorganic fertilizers. Application of chicken manure and combinations of chicken manure $+\mathrm{EM}_{4}$ at the age of 60 dap could increase the index of leaf area compared to $\mathrm{EM}_{4}$ treatment, but at the age of 75 dap, the administration of chicken manure $+\mathrm{EM}_{4}$ could increase the index of leaf area compared to only chicken manure or only $\mathrm{EM}_{4}$. The index of leaf area value was at 4-7 inclined ramps. ${ }^{12}$ The index of leaf area in rice plants could reach $>6$ depending on the varieties and the availability of nutrients. ${ }^{13}$ Thus, the optimum supply of nutrients increased the index of leaf area on plants so that more sunlight could be absorbed for photosynthesis. It is useful to produce enough assimilates. The leaves are part of plants influence in the photosynthesis process. $^{9}$ The greatest photosynthesis process in leaves was at the third and fourth sections of rice plant leave. ${ }^{10}$

\section{Total dry weight of rice plants}

Observations of the total dry weight of rice plants at 60 dap showed that the application of $100 \%$ and $150 \%$ inorganic fertilizer could increase the total dry weight compared to $50 \%$ inorganic fertilizer and without fertilizer. However, at the age of 75-105 dap, 50\% and 150\% inorganic fertilizer resulted in the same total amount of

Table 1. Average height of rice plants due to the treatment effect of inorganic fertilizers and organic materials in a variety of plant ages.

\begin{tabular}{|c|c|c|c|c|c|c|}
\hline Treatment & \multicolumn{6}{|c|}{ Plant height (cm), at the age of ... dap } \\
\hline \multicolumn{7}{|l|}{ Inorganic fertilizer } \\
\hline Without fertilization & $38.51 \mathrm{a}$ & $52.19 \mathrm{a}$ & $62.38 \mathrm{a}$ & $69.34 \mathrm{a}$ & $81.74 \mathrm{a}$ & $82.00 \mathrm{a}$ \\
\hline $50 \%$ of inorganic fertilizer & $39.36 \mathrm{a}$ & $54.56 \mathrm{a}$ & $67.26 \mathrm{~b}$ & $73.67 \mathrm{~b}$ & $87.04 \mathrm{~b}$ & $87.36 \mathrm{~b}$ \\
\hline $100 \%$ of inorganic fertilizer & $36.72 \mathrm{a}$ & $54.49 \mathrm{a}$ & $68.98 \mathrm{~b}$ & $74.52 \mathrm{~b}$ & $86.94 \mathrm{~b}$ & $87.13 \mathrm{~b}$ \\
\hline $150 \%$ of inorganic fertilizer & $40.18 \mathrm{a}$ & $57.76 \mathrm{~b}$ & $73.00 \mathrm{c}$ & $79.83 \mathrm{c}$ & $89.02 \mathrm{~b}$ & $89.46 \mathrm{~b}$ \\
\hline LSD $5 \%$ & tn & 2.97 & 3.14 & 3.79 & 3.08 & 3.00 \\
\hline \multicolumn{7}{|l|}{ Organic materials } \\
\hline $\mathrm{EM}_{4}$ & $36.13 \mathrm{a}$ & $52.12 \mathrm{a}$ & $65.40 \mathrm{a}$ & $70.86 \mathrm{a}$ & $84.41 \mathrm{a}$ & $84.75 \mathrm{a}$ \\
\hline Chicken manure & $39.57 \mathrm{~b}$ & $56.01 \mathrm{~b}$ & $68.97 \mathrm{~b}$ & $75.90 \mathrm{~b}$ & $86.58 \mathrm{a}$ & $86.80 \mathrm{a}$ \\
\hline Chicken manure + EM4 & $40.38 \mathrm{~b}$ & $56.12 \mathrm{~b}$ & $69.35 \mathrm{~b}$ & $76.27 \mathrm{~b}$ & $87.50 \mathrm{a}$ & $87.91 \mathrm{a}$ \\
\hline LSD $5 \%$ & 3.15 & 3.43 & 3.62 & 4.38 & tn & tn \\
\hline
\end{tabular}

Numbers that are accompanied by the same letter in the same column means that there are no significant differences according to LSD 5\%, dap (days after planting), tn (not significant)

Table 2. Average number of tillers per clump due to the influence of inorganic fertilizer treatment at various ages of the plant.

\begin{tabular}{|c|c|c|c|c|c|c|}
\hline \multirow[t]{2}{*}{ Treatment } & \multicolumn{6}{|c|}{ Number of tillers, at the age of ... dap } \\
\hline & 30 & 45 & 60 & 75 & 90 & 105 \\
\hline \multicolumn{7}{|l|}{ Inorganic fertilizer } \\
\hline Without fertilization & $11.04 \mathrm{a}$ & $22.47 \mathrm{a}$ & $27.00 \mathrm{a}$ & $22.23 \mathrm{a}$ & $17.22 \mathrm{a}$ & $15.28 \mathrm{a}$ \\
\hline $50 \%$ of inorganic fertilizer & $11.26 \mathrm{a}$ & $25.00 \mathrm{ab}$ & $29.86 \mathrm{ab}$ & $25.31 \mathrm{~b}$ & $20.21 \mathrm{~b}$ & $18.12 \mathrm{~b}$ \\
\hline $100 \%$ of inorganic fertilizer & $11.41 \mathrm{a}$ & $27.90 \mathrm{~b}$ & $33.58 \mathrm{bc}$ & $28.29 \mathrm{c}$ & $22.38 \mathrm{c}$ & $19.96 \mathrm{c}$ \\
\hline $150 \%$ of inorganic fertilizer & $12.52 \mathrm{a}$ & $29.62 \mathrm{c}$ & $35.19 \mathrm{c}$ & $29.70 \mathrm{C}$ & $23.22 \mathrm{c}$ & $20.43 \mathrm{c}$ \\
\hline LSD $5 \%$ & tn & 3.70 & 3.87 & 2.77 & 1.67 & 1.39 \\
\hline
\end{tabular}

Numbers that are accompanied by the same letter in the same column means that there are no significant differences according to LSD 5\%, dap (days after planting), tn (not significant). 
dry weight on rice plants. The use of a combination of organic and inorganic fertilizers could enhance plant growth. The plants would grow well when the nutrients were available and sufficient. ${ }^{11}$ Nutrient absorption indirectly increased the photosynthesis process that produced photosynthate, which is stored in plant tissues, and thus increased plant dry weight. ${ }^{14}$

\section{Plant growth rate}

Inorganic fertilizer significantly influenced rice plants at the age of 30-60 dap and 60-105 dap. Data in Table 3 showed that the plants' growth rate in the vegetative phase is higher than the generative phase. The application of inorganic fertilizer increased the growth rate from the vegetative until the generative phase. On vegetative growth of the plants at ages between 30 and 60 days after planting, the treatment of $150 \%$ inorganic fertilizer and $100 \%$ inorganic fertilizer resulted in the same growth rate, while generative growth at the age of 60-105 days after planting with application of $50 \%$ and $150 \%$ inorganic fertilizer resulted in the same growth rate. During vegetative growth, the nutrient phosphor contributed to optimum plant growth at $0.3-0.5 \%$ of the dry weight. C3-plants with a value of CGR $200 \mathrm{~kg} \mathrm{ha}^{-1}$ day $^{-1}$ are considered quite $\operatorname{good}^{12}$

\section{Number of panicles per clump and empty grain per clump (\%)}

The results showed that the application of $150 \%$ inorganic fertilizer results in the same number of panicles per clump with $50 \%$ and $100 \%$ inorganic fertilizer, but no fertilization treatment resulted in a lower number of panicles per clump. Provision of inorganic fertilizer with a high dose resulted in more tillers but fewer panicles. The decreasing number of panicles formed was influenced by genetic factors. The number of productive tillers affected the amount of crop harvested. This result shows that 10 tillers produce 200 grains per panicle, while 15 tillers only produced 100 grains per panicle.

An increase in the percentage of empty grain was positively correlated with the increased dose of fertilizer. With higher doses of inorganic fertilizer, the empty grain percentage also increased. Application of $100 \%$ and $150 \%$ inorganic fertilizer has a higher percentage of empty grain $(33.39 \%$ and $34.44 \%$ ), compared to no fertilizer and $50 \%$ inorganic fertilizers $(29.91 \%$ and $30.87 \%$ ). The intensity of the blast disease increased in accordance with the increasing nitrogen fertilizer, with a percentage of $28.5 \%$. The excessive usage of nitrogen makes the plants susceptible to blast disease pathogens. This result states that the application of $150 \%$ NPK inorganic fertilizers in recommended doses on local rice cultivars can lead to blast disease of around $8.41 \%{ }^{15}$

\section{Weight of 1000 grains and the weight of dry milled grain per hectare (Ha)}

The weight of 1000 grains in Table 4 shows that the treatment of $50 \%$ inorganic fertilizers combined with chicken manure $+\mathrm{EM}_{4}$ weighted 1000 grain higher than other treatments, but did not differ from $50 \%$ inorganic fertilizer combined with chicken manure, $100 \%$ inorganic fertilizer combined with $\mathrm{EM}_{4}$, and $100 \%$ inorganic fertilizer+chicken manure $+\mathrm{EM}_{4}$. It was due to the application $\mathrm{EM}_{4}$, which can be used as a starter or activator for inorganic fertilizers, to improve the response of inor-

Table 3. Total average of dry weight due to the treatment influence of inorganic fertilizer at various ages of the plant.

\begin{tabular}{|c|c|c|c|c|c|c|}
\hline \multirow[t]{2}{*}{ Treatment } & \multicolumn{6}{|c|}{ 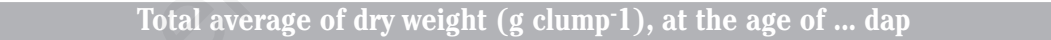 } \\
\hline & 30 & 45 & 60 & 75 & 90 & 105 \\
\hline \multicolumn{7}{|l|}{ Inorganic fertilizer } \\
\hline Without fertilization & $2.49 \mathrm{a}$ & $11.27 \mathrm{a}$ & $26.08 \mathrm{a}$ & $31.22 \mathrm{a}$ & $48.01 \mathrm{a}$ & $53.52 \mathrm{a}$ \\
\hline $50 \%$ of inorganic fertilizer & $3.07 \mathrm{a}$ & $13.11 \mathrm{a}$ & $27.83 \mathrm{a}$ & $44.44 \mathrm{~b}$ & $62.01 \mathrm{~b}$ & $77.45 \mathrm{~b}$ \\
\hline $100 \%$ of inorganic fertilizer & $3.09 \mathrm{a}$ & $11.57 \mathrm{a}$ & $34.44 \mathrm{~b}$ & $45.61 \mathrm{~b}$ & $64.32 \mathrm{~b}$ & $79.37 \mathrm{~b}$ \\
\hline $150 \%$ of inorganic fertilizer & $2.84 \mathrm{a}$ & $16.70 \mathrm{a}$ & $37.49 \mathrm{~b}$ & $50.13 \mathrm{~b}$ & $73.58 \mathrm{~b}$ & $79.32 \mathrm{~b}$ \\
\hline LSD 5\% & $\operatorname{tn}$ & $\operatorname{tn}$ & 6.90 & 6.86 & 13.59 & 10.39 \\
\hline
\end{tabular}

Table 4. Average weight of 1000 grain, grain weight per square meter, and grain weight per hectare, due to the treatment effect of inorganic fertilizer and organic materials (conversion of GKP to MPD).

\begin{tabular}{|c|c|c|}
\hline Without fertilization + EM4 & $22.21 \mathrm{abc}$ & $2.50 \mathrm{a}$ \\
\hline Without fertilization + chicken manure & $22.10 \mathrm{ab}$ & $2.66 \mathrm{ab}$ \\
\hline Without fertilization + chicken manure $+\mathrm{EM}_{4}$ & $22.17 \mathrm{abc}$ & $2.99 \mathrm{abc}$ \\
\hline $50 \%$ of Inorganic fertilizer $+\mathrm{EM}_{4}$ & $21.94 \mathrm{ab}$ & $3.05 \mathrm{abc}$ \\
\hline $50 \%$ of Inorganic fertilizer + chicken manure & $23.21 \mathrm{~d}$ & $4.18_{\mathrm{f}}$ \\
\hline $50 \%$ of Inorganic fertilizer + chicken manure $+\mathrm{EM}_{4}$ & $23.23 \mathrm{~d}$ & $4.20 \mathrm{f}$ \\
\hline $100 \%$ of Inorganic fertilizer $+\mathrm{EM}_{4}$ & $23.09 \mathrm{~cd}$ & 3.95 ef \\
\hline $100 \%$ of Inorganic fertilizer + chicken manure & $21.84 \mathrm{ab}$ & $3.36 \mathrm{cde}$ \\
\hline $100 \%$ of Inorganic fertilizer + chicken manure+EM 4 & $22.55 \mathrm{bcd}$ & $3.92 \mathrm{ef}$ \\
\hline $150 \%$ of Inorganic fertilizer $+\mathrm{EM}_{4}$ & $22.10 \mathrm{abc}$ & 3.76 def \\
\hline 150\% of Inorganic fertilizer + chicken manure & $21.55 \mathrm{a}$ & $3.19 \mathrm{bcd}$ \\
\hline $150 \%$ of Inorganic fertilizer + chicken manure $+\mathrm{EM}_{4}$ & $22.02 \mathrm{ab}$ & 3.59 cdef \\
\hline LSD 5\% & 0.57 & 0.79 \\
\hline
\end{tabular}

Numbers that are accompanied by the same letter in the same column means that there are no significant differences according to LSD 5\%. 
ganic fertilizer on plant growth and improve the productivity. Organic fertilizer could be a supplement for inorganic fertilizer so the plants grow better, resulting in better harvest crop. ${ }^{9}$

The result showed that $150 \%$ inorganic fertilizer generated the same 1000 grain weight with the treatment without fertilization. The inappropriate use of inorganic fertilizer would reduce nutrients in the soil so that plant responses were decreased. It was caused by the unutilized nutrients that could turn into pollutant. ${ }^{16}$

Data of dry milled grain weight per hectare in Table 4 showed that $50 \%$ inorganic fertilizer combined with chicken manure $+\mathrm{EM}_{4}$ was higher by $4.20 \mathrm{t} \mathrm{ha}^{-1}$, but did not differ from $50 \%$ inorganic fertilizer combined with chicken manure, as well as $100 \%$ and $150 \%$ inorganic fertilizer combined with chicken manure+EM $\mathrm{EM}_{4}$ and also treatment with $\mathrm{EM}_{4}$ only. The application of inorganic fertilizer and organic materials on rice crops could increase the harvest by $68 \%$ compared with crops without chemical fertilizers. The direct application of inorganic fertilizer resulted in a quick response to plant growth so that it could increase plant productivity. This is in accordance with the results showing that $1.5 \mathrm{t} \mathrm{ha}^{-1}$ organic fertilizer combined with $50 \%$ inorganic fertilizers in recommended doses gave the best results, compared to inorganic fertilizers (NPK 100:50:50 kg ha-1) or 2 tons ha-1 of organic fertilizers. ${ }^{9}$ The harvested crop of treatment NPK+pig manure produced 8572 $\mathrm{kg} \mathrm{ha}^{-1}$ grains, while the use of NPK fertilizer produced $7795 \mathrm{~kg} \mathrm{ha}^{-1}$ grains, which was an increase of $9.06 \%{ }^{17}$

\section{Conclusions}

The use of organic materials (chicken manure and chicken manure + EM4) can reduce the need for NPK inorganic fertilizer with increasing productivity up to $50 \%$ from 4.18-4.20 $\mathrm{t} \mathrm{ha}^{-1}$ and are relatively the same with $100 \%$ and $150 \%$ NPK inorganic fertilizer. In addition, the harvest results increased by $68 \%$ compared to treatment without NPK inorganic fertilizer on the equatorial agro-ecosystem.

\section{References}

1. Wahyunto, Shofiyati R. Wilayah Potensial Lahan Kering Untuk Mendukung Pemenuhan Kebutuhan Pangan di Indonesia. Badan Litbang Pertanian. Kementerian Pertanian, 2012:297-315.

2. Badan Pusat Stastistik Kalimantan Barat. Kalimantan Barat Dalam Angka. Badan Pusat Stastistik Kalimantan Barat. Pontianak; 2014.

3. Kaya E. Pengaruh Kompos Jerami, Pupuk NPK Terhadap N-Tersedia Tanah, Serapan N, Pertumbuahan, dan Hasil Padi Sawah (Oryza sativa L.). J Agrologia 2013;2:43-50.

4. Rusdy A. Pemberian Pupuk Hayati dan Fosfor Pada Padi Gogo Terhadap Serangan Kepik Hijau. J Floratek 2010;5: 31-42.

5. Suyono AD, Citraresmini A. Komposisi Kandungan Fosfor Pada Tanaman Padi Sawah (Oryza sativa L.) Berasal Dari Pupuk P dan Bahan Organik. BionaturaJurnal Ilmu-Ilmu Hayati dan Fisika 2010;12:126-35.

6. Ruhukail NL. Pengaruh Penggunaan $\mathrm{EM}_{4}$ yang Dikulturkan pada Bokashi dan Pupuk Anorganik Terhadap Produksi Tanaman Kacang Tanah (Arachis hypogaea L.) di Kampung Wanggar Kabupaten Nabire. J Agroforestri 2011;4:114-20.

7. Kasniari DN, Supadma AAN. Pengaruh Pemberian Beberapa Dosis Pupuk $(\mathrm{N}, \mathrm{P}, \mathrm{K})$ dan Jenis Pupuk Alternatif terhadap Hasil Tanaman Padi (Oryza sativa L.) dan Kadar N,P,K Inceptisol
Selemadeg, Tabanan. J Agritrop 2007;26:168-76.

8. Higa T, Wididana. Teknologi Effective Microorganisme. Jakarta: Indonesia Kyusei Nature Farming Societies (IKNFS) dan PT. Songgolangit Persada; 1996.

9. Siavoshi M, Nasiri A, Laware SL. Effect of organic fertilizer on growth and yield components in rice (Oryza sativa L.). J Agricultural 2011;3:217-24.

10. Yoshida S. Fundamentals of Rice Crop Science. Los Banos: Internasional Rice Research Institute; 1981.

11. Lingga P, Marsono. Petunjuk Penggunaan Pupuk Edisi Revisi. Jakarta: Penebar Swadaya; 2000.

12. Gardner FP, Pearce RB, Mitchell RL. Fisiologi Tanaman Budidaya. Jakarta: Universitas Indonesia Press; 2008.

13. Sitompul SM, Guritno B. Analisis Pertumbuhan Tanaman. Yokyakarta: Gajah Mada University Press; 1995.

14. Idwar, Yoseva S, Norkhalimah S. Respon Beberapa Varietas Padi Gogo (Oryza sativa L.) terhadap Pemupukan N,P dan K di Tanah Inceptisol. Seminar Nasional BKS PTN Barat Bandar Lampung, 19-21 Agustus 2014; 104114.

15. Hasfiah O. Uji Daya Hasil Dan Ketahanan Padi Gogo Lokal Terhadap Penyakit Blas (Pyricularia oryzae) Pada Berbagai Dosis Pemupukan. Berkala Penelitian agronomi 2012;1:26-36.

16. Abdurachman A, Dariah A, Mulyani A. Strategi dan Teknologi Pengelolaan Lahan Kering Mendukung Pengadaan Pangan Nasional. J Litbang Pertanian 2008;27:43-9.

17. Ming L, Pei LZ, Lin ZT, et al. Discrepancy in response of rice yield and soil fertility to long-term chemical fertilization and organic amendments in paddy soils cultivated from infertile upland in subtropical china. J Agricult Sci China 2011;10:259-66. 